\title{
PERAN SUPERVISI PENDIDIKAN UNTUK MENINGKATKAN MUTU PENDIDIKAN AGAMA ISLAM
}

\author{
YOPIE ANDI RESTARI
}

E-mail : yopieandirestari10@gmail.com

\begin{abstract}
ABSTRAK
Supervisi pendidikan merupakan sebuah pelayanan dan bantuan kepada sekolah dalam mengembangkan situasi belajar mengajar ke arah yang lebih baik, dengan cara memberikan bimbingan dan pengarahan kepada guru dan staf sekolah. Dalam hal ini berkaitan dengan supervisi pendidikan islam yang bertujuan untuk memberi panduan dan arahan guna mengembangkan kemampuan individu sekaligus dalam meningkatkan kualitas pendidikan. Dalam meningkatkan mutu pendidikan agama islam yang pentih dilakukan harus komitmen untuk membangun dan berjalan bersama. Ada beberapa trik dan tips supervise dalam lembaga pendidikan islam yaitu membangun kesadaran setiap guru dan staf di sekolah, meningkatkan pemahaman terhadap tugas amsing-masing profesi, kepedulian dikalangan guru dan staf terhadap peserta didik dan lingkungannya, dan mempunyai sikap komitmen terhadap suatu pekerjaan. Tujuan akhir dari supervise adalah peningkatan situasi belajar-mengajar, peningkatan proses belajar, dan hasil belajar murid untuk meningkatkan situasi belajar mengajar, kemampuan guru harus ditingkatkan terlebih dahulu. Untuk itu, diperlukan identifikasi tentang kelemahan dan kelebihna guru agar pelaksana supervise ( akademik ) berjalan efektif dan efisien. Setelah terindetifikasi, maka tugas supervisoradalh membimbing guru yang pada akhirnya mengarah kepada tercapainya masing-masing tujuan.
\end{abstract}

Kata Kunci : Peran Supervisi Pendidikan, Mutu, Pendidikan Agama Islam. 


\section{LATAR BELAKANG}

Pendidikan merupakan hal yang sangat penting dalam kehidupan karena tanpa adanya pendidikan kita tidak akan bisa melakukan aktifitas secara baik. Dalam hal ini dibutuhkan lembaga-lembaga sekolah yang berusaha meningkatkan mutu pendidikannya. Sehingga bisa mencetak lulusan yang berprestasi dan berakhlak mulia.

supervise adalah suatu usaha menstimulir, mengkoordinir,dan membimbing secara continue pertumbuhan guru di sekolah baik secara individual maupun secara kolektif, agar lebih mengerti dan lebih efektif dalam mewujudkan seluruh fungsi pengajaran, dengan demikian mereka dapat menstimulir dan membimbing pertumbuhan tiap murid secara continue, serta mampu dan cakap berpartisipasi dalam masyarakat demokrasi modern.

Jadi, Supervisi merupakan suatu aktivitas pembinaan yang direncanakan untuk membantu guru dan pegaewai sekolah lainya dalam melakukan pekerjaan mereka secara efektif. Dalam hal ini guru mempunyai peran.

\section{RUMUSAN MASALAH}

Berdasarkan uraaian diatas dapat dirumuskan masalah sebagai berikut :

apa saja permasalahan dalam peningkatkan mutu pendidkan agama islam melalui peran supervise pendidikan, Bagaimana peran supervise pendidikan untuk meningkatkan mutu pendidikan agam islam, Apa saja tips dan trik supervise pendidikan dalam meningkatkan mutu pendidikan agama islam.

\section{TUJUAN}

Peningkatan mutu pendidikan islam penting untuk dilakukan mengingat terwujudnya mutu tidak boleh tidak harus ada komitmen bersama untuk membangun dan berjalan bersama. Oleh karena itu, salah satu upaya peningkatan mutu sebuah lembaga pendidikan adalah adanya supervisi yang akan memberikan timbal balik dan masukan guna terwujudnya pendidikan termasuk di dalamnya pendidik dan tenaga kependidikan.

Adapun prinsip dari supvervisi pendidikan islam adalah: supevisi hendaknya bersifat konstruktif dan kreatif, supervisi yang mudah dilaksanakan dan sederhana, supervise bersifat informal pelaksanaanya, supervisi dapat memberikan perasaan aman kepada pegawai-pegawai sekolah, supervise didasarkan hubungan professional, supervise tidak bersifat mendesak (otoriter), supervisi tidak boleh didasarkan atas kekuasaan ataupun pangkat, supervise idak mencari kesalahan atau kekurangan, dan supervise hendaknya bersifat preventif ( mencegah adanya hal-hal negative), korektif 
(memperbaiki kesalahan-kesalahan yang telah diperbuat), dan kooperatif (mencari kesalahn atau kekurangan dan usaha memperbaikinya dilakukan bersama supervisor).

\section{PEMBAHASAN}

Supervisi mempunyai peran dalam meningkatkan mutu pendidikan islam, peran supervise merupakan keikutsertakan seseorang dalam suatu hal yang menyangkut potensi yang dimiliki. Dan mempunyai peran membina dalam bimbingan terhadap perbaikan mutu pendidikan di sekolah.

Menurut Sabandi (2013) Peningkatan kualitas pembelajaran perlu dilakukan secara berkesinambungan seiring perkembangan ilmu pengetahuan,teknologi, serta sosial ekonomi dan budaya masyarakat. Pendekatan peningkatan keprofesionalan guru tersebut dapat dilakukan dengan teknik supervise, menumbuhkan budaya organisasi pembelajaran, dan kegiatan pelatihan. Dengan menggunakan pendekatan tersebut, dapat dilakukan peningkatan kinerja lembaga melalui peningkatan keprofesionalan guru secara berkelanjutan baik dilakukan secara perorang maupun kelompok.

Ada beberapa tips dan trik supervise dalam lembaga pendidikan islam adalah :

a. Membangun kesadaran : setiap guru dan staf sekolah harus menyadari tugas dan fungsinya masing-masing, bahwa mereka memiliki peran penting dalam mengembangkan pribadi - pribadi peserta didik

b. Meningkatkan pemahaman : langkah berikutnya adalah meningkatkan pemahaman mereka agar dapat melaksanakan tugas dan fungsinya tersebut dengan baik dan efektif

c. Kepedulian : berikutnya adalah menumbuhkan kepedulian dikalangan guru dan staf lainya, sehingga mereka peduli terhadap peserta didik dan lingkungannya.

d. Komitmen : selanjutnaya menumbuhkan komitmen yang tinggi dalam diri kita sebagai guru, sehingga memiliki rasa aman, nyaman, dan menyenangkan dalam mengemban tugas dan fungsinya.

Dalam hal ini, tujuan akhir dari supervise adalah peningkatan situasi belajarmengajar, peningkatan proses belajar, dan hasil belajar murid untuk meningkatkan situasi belajar mengajar, kemampuan guru harus ditingkatkan terlebih dahulu. Untuk itu, diperlukan identifikasi tentang kelemahan dan kelebihna guru agar pelaksana supervise ( akademik ) berjalan efektif dan efisien. Setelah terindetifikasi, maka tugas supervisoradalh membimbing guru yang pada akhirnya mengarah kepada tercapainya masing-masing tujuan. 


\section{PENUTUP}

\section{Kesimpulan}

Peningkatan kualitas pembelajaran perlu dilakukan secara berkesinambungan seiring perkembangan ilmu pengetahuan,teknologi, serta sosial ekonomi dan budaya masyarakat. Pendekatan peningkatan keprofesionalan guru tersebut dapat dilakukan dengan teknik supervise, menumbuhkan budaya organisasi pembelajaran, dan kegiatan pelatihan. Dengan menggunakan pendekatan tersebut, dapat dilakukan peningkatan kinerja lembaga melalui peningkatan keprofesionalan guru secara berkelanjutan baik dilakukan secara perorang maupun kelompok.

Ada beberapa trik dan tips supervise dalam lembaga pendidikan islam yaitu membangun kesadaran setiap guru dan staf di sekolah, meningkatkan pemahaman terhadap tugas amsing-masing profesi, kepedulian dikalangan guru dan staf terhadap peserta didik dan lingkungannya, dan mempunyai sikap komitmen terhadap suatu pekerjaan.

tujuan akhir dari supervise adalah peningkatan situasi belajar-mengajar, peningkatan proses belajar, dan hasil belajar murid untuk meningkatkan situasi belajar mengajar, kemampuan guru harus ditingkatkan terlebih dahulu. Untuk itu, diperlukan identifikasi tentang kelemahan dan kelebihna guru agar pelaksana supervise ( akademik ) berjalan efektif dan efisien. Setelah terindetifikasi, maka tugas supervisoradalh membimbing guru yang pada akhirnya mengarah kepada tercapainya masing-masing tujuan.

\section{Saran}

Demikianlah artikel mengenai "peran supervise pendidikan umtuk meningkatkan mutu pendidikan agama islam" semoga aritkel ini bermanfaat untuk kita semua. Penulis mengharapkan artikel ini dapat menambah wawasan dan ilmu pengetahuan kita dan senantiasa mendekatkan diri kepada Allah SWT. 


\section{DAFTAR PUSTAKA}

Sabandi, A. (2013). Supevisi Pendidikan Untuk Pengembangan

Profesionalitas Guru Berkelanjutan. Pedagogi, Jurnal Ilmu

Pendidikan, XIII(2), 1-9, Retrived from

http://ejournal.unp.ac.id/index.php/pedagogi/article/view/4275

Fauziah. (2017). Supervisi Pendidikan Sebagai Upaya Peningkatan Mutu Pendidikan Islam. Jurnal Tarbiyatuna, 2(1) Retrived from http://erepository.perpus.iainsalatiga.ac.id/543/1/Siti\%20Lazimatun\%20N. 11110191.pdf

Suhadi, E. (2014). Pengembangan Motivasi dan Kompetensi Guru dalam Peningkatan Mutu Pembelajaran di Madrasah. Jurnal Pendidikan Islam, 3(1), p-ISSN: 2252-5793 Retrived from ejournal.uika-bogor.ac.id

Makawimbang, Jerry H.(2011). Supervisi dan Peningkatan Mutu Pendidikan. Bandung: Alvabeta.

Mulyasa.(2010). Implementasi Kurikulum Tingkat Satuan Pendidikan, Kemandirian dan Kepala Sekolah. Jakarta: PT Bumi Aksara 